\title{
Exploring Narratives of Scarcity, Uncertainty, and Opportunity in Women's Sports Coverage During the COVID-19 Pandemic
}

\author{
Ellen J. Staurowsky \\ Drexel University \\ and Ithaca College
}

\author{
Benjamin Koch, \\ Grace Dury, and Cooper Hayes \\ Ithaca College
}

\begin{abstract}
In this essay, the authors explored Pinsker's conception of two pandemics, as reflected in the concerns expressed about the future of women's sport, prospects for female athletes, and the security of women leaders in sport as they emerged in articles published in national news sources. The purpose of this essay was to capture, in a limited way, how women's sport concerns surfaced in the media in the aftermath of a forced industry shutdown; to gauge reactions, assess real and perceived threats; and to examine how and whether this crisis inspired positive thoughts about women's sport opportunities for the future. Our work is based on the tracking of articles published in major news outlets about the impact of the pandemic on women's sport from March 10, 2020, to May 25, 2020. Readings of the collected articles revealed several themes that fit within the two pandemics framework: reactions to the loss of momentum in women's sport; fears regarding a reversal in gains made by women's sport in the marketplace as competition for limited resources escalates; concerns about women's sport participation decreasing due to cuts and delays in programs; and a focused commitment to gender equity and maintaining momentum, even in the face of significant headwinds.
\end{abstract}

Keywords: media coverage, female sports, global health crisis

"No visible records." That was the message posted on the Just Women's Sports schedule of events page about a month after the COVID-19 pandemic shuttered sporting events around the world (Just Women's Sports, 2020). The stark emptiness of the page testified to the grim reality of a global health crisis that necessitated the abrupt postponement or cancellation of sport seasons, events, and competitions from the youth level through the pros.

During such an unprecedented time, how have women's sport entities, women athletes, and women working in the sport industry fared, and what does the future 
hold? Complicated questions to be sure, given the seismic shift in a world economy that has left no social institution unshaken. Race and class divisions that existed before the COVID-19 virus have yielded what The Atlantic's Joe Pinsker (2020) referred to as two pandemics in America, one where those with greater financial resources weather the moment and emerge relatively stable, while those without such advantages, if they survive, suffer life-altering consequences for generations to come.

Through a gendered lens, the pandemic has been experienced differently by men and women. As Helen Lewis (2020) wrote, "A pandemic magnifies all existing inequalities" (para. 3) with researchers projecting that it "will have a disproportionate negative effect on women and their employment opportunities" (Alon, Doepke, Olmstead-Rumsey, \& Tertilt, 2020, p. 1).

Within the sport industry, economic and social divides exist across race, class, and gender lines (Faller, 2019). Convergences around money, visibility, and perceived relevance historically separate men's and women's sport. As a case in point, the Fédération Internationale de Football Association Men's World Cup in 2018 was viewed by an audience of 3.572 billion, compared with an audience roughly a third of that size (one billion) for the 2019 FIFA (Fédération Internationale de Football Association) Women's World Cup (FIFA Staff, 2019). While professional opportunities for female athletes in individual sports, such as golf and tennis, have been firmly established for decades, women's professional leagues in team sports have faced a mix of challenges (Chaplain, 2020; Kaplan, 2020).

Vast gaps in pay render women's professional sport opportunities part-time occupations and top U.S. female pro athletes global itinerants, traveling to other countries to pursue professional opportunities not available in the United States. In contrast, men's professional sport contracts set elite male athletes up for economic security long past their playing days (Verdola, 2019). In 2020, women athletes continue to receive $1 \%$ of sponsorship dollars spent by global brands, and women's sport garners a mere 5\% of sports media coverage (Staurowsky et al., 2020). Cheri Kemp, commissioner of the National Fastpitch Softball League, captured the essence of Pinsker's (2020) notion of two pandemics when she observed that both men's and women's sports were navigating high seas during the crisis, but men's sports were yachts and women's sports were canoes (Peterson, 2020).

In this essay, we explored Pinsker's (2020) conception of two pandemics, as reflected in the concerns expressed about the future of women's sport, prospects for female athletes, and the security of women leaders in sport as they emerged in articles published in national news sources. The purpose of this essay was to capture, in a limited way, how women's sport concerns surfaced in the media in the aftermath of a forced industry shutdown.

Our work was based on tracking articles published in major news outlets about the impact of the pandemic on women's sport between March 10, 2020, and May 25, $2020(n=102)$, through a daily Google search. The bookend to this work is an acknowledgement that women's sport in the months and years immediately preceding the pandemic were marked, in part, by a paradigm shift in the way women's sport, female athletes, and women working in the sport industry were viewed by sport fans, as well as sport industry insiders. Thus, we began by documenting a prepandemic narrative of women's sport empowerment, followed with a report on themes of scarcity and uncertainty, as well as themes of silver linings and opportunity, and concluded with thoughts to consider as the pandemic continues. 


\section{Women's Sport Prepandemic: Unprecedented Moments of Accomplishment and Triumph}

In its annual report on the sport industry outlook for growth, the rise of women's sport topped the list of predictions made by the Deloitte Center for Technology, Media, and Telecommunications for 2020. The momentum building around women's sports was credited with the opening of "unparalleled opportunities for the creation of new professional leagues, franchises, corporate sponsorships and increased ticket sales." The report concluded, "This groundswell could represent a tipping point for women's sports, powered by the increasing exposure of teams and athletes" (Giorgio, 2020, p. 4).

Indicative of the trend, University of California, Los Angeles gymnast Katelyn Ohashi's electrifying floor exercise routine conservatively received 117 million views on social media, garnering her two ESPY awards for both the best viral moment in sports and the best play in sports in 2019 (Associated Press, 2019). The summer of 2019 reverberated with the excitement of the U.S. Women's National Soccer Team winning its fourth World Cup, with 14 million viewers watching the final match on Fox Sports (Dockery, 2019). And Carol Kallan, USA Basketball Women's National Team Director, made history when she became the first woman to be elected president of an International Basketball Federation zone, the zone known as FIBA Americas (USA Basketball Staff, 2019).

Activism by women athletes and advocacy for women's sport was gaining support in a virtual universe. Skating in the National Hockey League's premier passer event during the 2019 All-Star Weekend, women's ice hockey player Brianna Decker won the event. When fans learned that Decker was ineligible to receive the $\$ 25,000$ prize because she was there as an exhibition skater, they rallied with chants of Pay Decker, prompting hockey equipment manufacturer CCM to do just that (Berkman, 2019).

In the run-up to the Women's World Cup, players on the U.S. Women's National Soccer Team emerged as spokeswomen for a generation of female athletes who would no longer be put off with rhetorical statements about equality and fairness when they sued the United States Soccer Federation, alleging pay inequities and sex discrimination (Clarke, 2019). In a similar fashion, women ice hockey players boycotted the National Women's Hockey League and set out to create the Professional Women's Hockey Players Association, seeking livable wages and better work conditions. Carrying over into 2020, the Women's National Basketball Association (WNBA) and its players union agreed on a collective bargaining agreement that increased salaries and provided new maternity benefits (Megdal, 2020).

Discussions about labor and working conditions occurred as television coverage started to expand for women's sport properties. The National Women's Hockey League entered its 2019 season with an increased schedule of 24 games, as well as new sponsors and owners (Berkman, 2019). A multiyear television deal with CBS Sports Network expanded on existing arrangements by committing to air 40 WNBA games during primetime and on weekends (Steinberg, 2019). In January of 2020, ESPN announced that it would broadcast the National Collegiate Athletic Association Division I women's basketball tournament nationally in its entirety (Kirpalani, 2020). 
As notable changes were happening to the infrastructure of women's professional sport, women were being hired into roles previously reserved for men in the sport industry. In the National Football League (NFL), where there had been zero female coaches, 14 female interns and eight full-time coaches were hired between 2015 and 2019 (Spain, 2020). The National Basketball Association, NHL, and Major League Baseball also made efforts to hire more female coaches, as well as more women in executive roles. Becky Hammon's signing as the National Basketball Association's first full-time assistant coach was followed with the hiring of an additional 11 full-time female coaches in the National Basketball Association as of the start of the 2019-2020 season (Gibson, 2020).

At the executive level, Valerie Camillo became the first president of an NHL franchise when she was hired by the Philadelphia Flyers in 2019 (Comcast, 2019). Attorney and former NHL executive Jessica Berman was appointed around the same time as Camillo to serve as deputy commissioner for the National Lacrosse League (Thomas, 2020).

As positive as this momentum change was, the reaction to its interruption by the COVID-19 pandemic demonstrates the precarious position women's sport holds within the sport industry. These positive narratives nest within a larger set of narratives that highlight deeply disturbing accounts of female gymnasts being sexually assaulted by sports medicine doctor, Larry Nassar (Lapook, 2019); failures of multiple sport governing bodies and institutions to protect female athletes from abusive coaches (Chakrabarti, 2019); and persistent budgetary inequities, wage gaps, and hostile sport workplaces (Staurowsky et al., 2020). Thus, the importance of the positive momentum was not just about record-breaking performances and hires that broke the glass ceiling, but efforts to overcome longstanding barriers to women's full participation in sport and gendered forces that exact substantial tolls on women who work and compete in the sport industry.

\section{Women's Sport Narratives During the Pandemic: Scarcity, Uncertainty, and Lost Opportunity}

On March 11, 2020, as public health officials worked to educate Americans about the virus and appropriate protocols, sport officials were sorting through options to continue or cancel competitions. The National Women's Soccer League preseason was cancelled, the start of the WNBA season postponed, and many other leagues shut down indefinitely (Mather, 2020). The National Collegiate Athletic Association took the step of cancelling not only the Division I men's and women's basketball championships, but all remaining winter and spring championships (Osburn, 2020).

The positive momentum that had been building around women's sport ended abruptly, as if, as one reporter noted, the "clock stopped" (Smith, 2020). Two Washington Post reporters noted how the pandemic's impact on the WNBA happened at a crucial time because the WNBA had been on the rise following a successful labor negotiation, brand refresh, and the hiring of Cathy Englebert as the first commissioner of the league (Copeland \& Wallace, 2020).

The New York Times reporter Juliet Macur (2020) wrote of the vulnerabilities associated with women's sport, where leagues are less well established and lack the 
infrastructure of men's leagues, and where female athletes with less lucrative contracts and fewer sponsorships live and work in much more tenuous circumstances than their male counterparts. Michael Whan, the commissioner of the Ladies Professional Golf Association, took to Twitter to ask sponsors for forbearance and leniency as events halted. Reminding sponsors that female golfers wanted to play, he wrote, "Please don't penalize them for my decisions!" (Minsberg, 2020).

Throughout the first 2 months of the pandemic, similar warnings about the disproportionate negative impact the sports shutdown would have on women's sport and a scarcity narrative appeared in coverage (Chaplain, 2020; Peterson, 2020; Pickman, 2020). Former Harvard women's soccer player and documentarian Susie Petrucelli (2020) offered a prediction that women's sports would be placed last in terms of priorities for allocations of resources and support.

Petrucelli's (2020) sensibility regarding priorities that match the framework of two pandemics is illustrated in the Canadian government's consideration of financial support to save the Canadian Football League. According to Donna Spencer (2020) of The Canadian Press, the Canadian Football League was seeking $\$ 150$ million from the federal government to avoid bankruptcy. She noted that, if the request were granted, the government's response would contrast sharply with the decision to deny the Canadian Women's Hockey League approximately $\$ 250,000$ to remain solvent, a decision that led to the CWHL's demise in 2019.

Fears about the tangible result of wavering or lack of commitment to women resulting in the loss of opportunity emerged in numerous stories. The Australian National Rugby League's support for women, for example, was called into question when it announced a hard date for a restart for men's competition, scheduled for May 28, 2020, while equivocating on when the women's four-team league would play (Shalala, 2020).

The international players union, known as FIFPro, issued a report calling for women's soccer worldwide to be supported financially. The report warned that the pandemic could devastate the women's game if proactive steps were not taken to protect it (Hillier, 2020). The union's most recent statistics reveal that $47 \%$ of female soccer players did not have contracts with their clubs compared with just $8 \%$ of male soccer players (Hillier, 2020).

\section{The Silver Lining in the Pandemic Narrative for Women's Sport}

Interspersed through the narratives about women's sport during the pandemic was one that emphasized opportunity, optimism, resolve, and innovation. Phaidra Knight, the eighth woman and first African American person to be inducted into the World Rugby Hall of Fame, did not discount the practical realities of financial hardship, but spoke to the need to look forward and beyond the burdens of the moment. She was careful to explain that "It's not what we accept" but went on to say, "For a female athlete, it's just another day" (Fine, 2020, para. 43).

That sentiment was reflected in a collaboration that occurred between the Women's Sports Foundation and Yahoo! Sports, resulting in a program called \#WeKeepPlaying. Featuring a panel of women athletes, among them Billie Jean 
King, the program was streamed on the Yahoo! Sports website on April 7, 2020. The panel focused on the need to continue pushing forward on equity issues despite the slowdown imposed by the pandemic (Wetzel, 2020).

Thayer Lavielle is executive vice president with Wasserman's The Collective, the arm of the sports and talent agency representing 150 elite female athletes. She discussed the importance of viewing the pandemic the importance of viewing the pandemic as a time when female athletes could enhance their brands. She described a forward-looking and forward-thinking mindset that takes women's sports on the offensive, especially for "women athletes who actually have larger platforms than some of the daytime media partners who would be showing their games" (Townes, 2020, para. 5).

\section{As the Pandemic Rolls, Some Thoughts to Consider}

When enough time has passed postpandemic, there will be opportunities to think more deeply about the lessons to be learned from the pandemic's impact on women's sport and how it was covered. As we capture some bit of the ongoing conversation about the current status and future of women's sport as reported in sport media during the 2-month span of time between March 10, 2020, and May 25, 2020, there are some things that present themselves as worthy of further consideration.

\section{Sport Media's Continuing Blindspot About the Value of Women's Sport}

At a time when there was little to no live sporting events or sport news being generated and when sport media was turning to properties such as the Korean Baseball League and novelty events such as cherry pit spitting, marble racing, lawn mower racing, and arm wrestling to fill programming voids, why did sport programmers fail to see more clearly the value of women's sports? (Chavez, 2020; Kim, 2020).

Lindsey Gibbs's (2020) analysis of the WNBA draft compared with the NFL draft, both of which aired during the pandemic, is instructive in this regard. While the WNBA draft was the most watched in many years, with a $123 \%$ increase in viewership (ESPN PR, 2020), the contrast between the magnitude and type of coverage devoted to the WNBA draft compared with the coverage of the NFL draft highlights the challenges women's sport faces in being presented as important sport properties, but also the failure of producers and programmers to see with clarity the value of women's sport (Gibbs, 2020).

The WNBA's 36 draftees selected in three rounds were covered in $2 \mathrm{hr}$, with only $44 \%$ of players receiving individual coverage during the broadcast, with the remaining picks (17-20) flashed on the screen while the coverage shifted to an interview with WNBA commissioner Cathy Englebert. The names of the 10 remaining draft picks were scrolled at the bottom of the screen during a tribute to Kobe Bryant and his daughter, Gigi, who had passed away just prior to the pandemic in a tragic helicopter crash. In contrast, the NFL draft was presented on three different networks-ABC, ESPN, and the NFL Network. The 32 picks in the 
first round were covered over a 4-hr window on the first of three nights of coverage. Time was set aside to showcase each pick, with highlight packages that emphasized the importance of the moment for the player. Coverage switched between players and at-home draft rooms of coaches and general managers and focused on the importance of each player selection to the respective franchise (Gibbs, 2020). The point worth considering here is assessing how much more both the WNBA and Entertainment and Sports Programming Network could have gained with more innovation and imagination.

\section{Two Pandemics, But One Sports World}

There are certain industry realities that may be covered over in the intensity of the pandemic moment. There can be no doubt that the male power structure within sport, connected as it is politically and to vast economic resources, does not willingly give ground in any moment and works to protect its center. Still, we might ask why those male centers of power started opening up to women just a few months and years ago. Why are we seeing more women in the NFL and other men's professional sports? An immediate answer is economic reality. According to de la Cretaz (2019), 86 million women watched the NFL in 2017. It makes good business sense for women to be viewed as legitimate partners in sporting enterprises. Beyond that is a professional sport industry that relies on a narrative of male superiority, but has had its fundamental weaknesses pointed out in the public domain now for some time. Note that the industry started to take women more seriously as public health concerns emanating from a growing awareness about the effects of concussive and subconcussive hits mounted and criticisms regarding the mistreatment of women rose as well. Conversations about women and sport framed within the context of scarcity and loss misses, at some level, the point that the sport industry needs women, as fans who are controllers of discretionary spending in households, as mothers who influence the sports their children play, and as workers (Staurowsky et al., 2020). That reality presents a foothold that has largely gone unrecognized in conversations about women and sport during the pandemic.

\section{Pandemic Disruption Leads to Asking Pointed Questions About Women's Sport Models}

During a time of turbulence, where women are located in relationship to the center of power may have long-term repercussions. Thus, it is notable that, in the midst of the pandemic, male professional tennis players, most specifically, Roger Federer, supported by Rafael Nadal, Andy Murray, and others, advocated for the merger of the men's Association of Tennis Professionals with the Women's Tennis Association, arguing that such a move would strengthen the sport and elevate prospects for all players, male and female (Reuters, 2020). Responding to a tweet from Federer, where he raised the subject publicly, support was voiced by legend Billie Jean King and some other female players, but curiously, a post from Serena Williams, indicating that those discussions were to have been confidential, was quickly removed from her Twitter feed, with little follow-up afterward (Satam, 2020). While most coverage of the discussion focused on the support from male players, a few noted that proposals to merge the two professional tennis tours have occurred 
before and failed because of the inability of the parties to reach agreement on key issues regarding equal standing for women and parity in terms of revenue sharing (Wertheim, 2020).

This concern about women's control over their sporting destinies arose in other ways in the media coverage during the pandemic. After reporting on the vulnerabilities women rugby teams are facing due to equivocal commitment from sport governing bodies during the pandemic, Kim Encel (2020) of ABC Australia suggested that the pandemic presented an opportunity for women's professional sport leagues to be "rewired" to better reflect the priorities of women and explore new business models for women-centric professional sport leagues. WNBA player, Diana Taurasi, broached a related subject when she asked why there were not more women investors in women's sport (Voepel, 2020). These central questions about business decisions made about women's sport and the priorities that drive them, most particularly whether those decisions are female centric, male centric, or a balance between the two, have had long histories.

\section{There Are More Than Two Pandemics in Sport}

The conversations about women's sport during the pandemic have largely been framed in a binary way, reflective of the structure of the sport system. Women's sport, however, is not a monolith. As efforts are made to confront issues that threaten women's professional- and elite-level sport, those efforts are encoded in White privilege, leaving us to wonder how the loss of opportunity and economic security during the pandemic has impacted female athletes of color, who are largely invisible in the coverage. Despite numerous articles documenting the disparate impact of the COVID-19 virus on communities of color (Arora, 2020), vulnerable due to preexisting health concerns, such as heart disease and diabetes, there is virtually no conversation as of this writing about how these understandings translate into the conversations regarding the pandemic's potential impact on sport participation of female athletes of color and health care considerations for athletes of color when sport resumes.

\section{References}

Alon, T., Doepke, M., Olmstead-Rumsey, J., \& Tertilt, M. (2020, March). The impact of COVID-19 on gender equality. Unpublished paper. Retrieved from http://faculty.wcas. northwestern.edu/ mdo738/research/COVID19_Gender_March_2020.pdf

Arora, R. (2020, May 4). Why the coronavirus pandemic is hitting communities of color particularly hard. TheHill.com. Retrieved from https://thehill.com/changing-america/ opinion/496034-why-the-coronavirus-pandemic-is-hitting-communities-of-color

Associated Press. (2019, April 17). UCLA's Katelyn Ohashi out to punctuate viral season with final statement. The Guardian. Retrieved from https://www.theguardian.com/ sport/2019/apr/17/katelyn-ohashi-ncaa-championships-viral-routine

Berkman, S. (2019, October 12). The only women's pro hockey league in North America plays on. The New York Times. Retrieved from https://www.nytimes.com/2019/10/12/ sports/hockey/nwhl-players.html

Chakrabarti, M. (2019, June 3). Will new Olympic abuse prevention policy make athletes safer? WBUR.org. Retrieved from https://www.wbur.org/onpoint/2019/06/03/olympicathletes-sexual-abuse-prevention-policy-safesport 
Chaplain, R. (2020, March 26). The uncertain future of the Women's Six Nations. ESPN.com. Retrieved from https://www.espn.com/rugby/story/_id/28958096/theuncertain-future-women-six-nations

Chavez, C. (2020, May 4). ESPN reaches Korean baseball organization broadcast deal. SI.com. Retrieved from https://www.si.com/mlb/2020/05/04/espn-korean-baseballorganization-games-broadcast-tv-schedule

Clarke, L. (2019, June 11). Double earners: The U.S. women's soccer team is fighting for greater gender equity while playing for a fourth World Cup title. The New York Times. Retrieved from https://www.washingtonpost.com/graphics/2019/sports/uswnt-equalpay-fight/

Comcast. (2019). Valerie Camillo: President, Business Operations, Philadelphia Flyers and Wells Fargo Center. Bio. Retrieved from http://www.comcastspectacor.com/ leadership/valerie-camillo

Copeland, K., \& Wallace, A. (2020, April 8). The WNBA was ascendant before the coronavirus changed everything. The Washington Post. Retrieved from https://www. washingtonpost.com/sports/2020/04/06/wnba-whats-next-during-coronavirus/

de la Cretaz, B. (2019, February 3). Super Bowl 2019 commercials from Olay, Bumble are a step in the right direction for female fans. NBCNews.com. Retrieved from https://www. nbcnews.com/think/opinion/super-bowl-2019-commercials-olay-bumble-are-step-rightdirection-ncna966096

Dockery, L. (2019, July 13). USWNT TV ratings for 2019 averaged 929K on US Englishlanguage television. Worldsoccertalk.com. Retrieved from https://worldsoccertalk. com/2019/07/13/uswnt-tv-ratings-201519-averaged-929k-us-english-language-television/

Encel, K. (2020, April 18). Coronavirus pandemic gives chance for women's footy to move beyond being a copy of men's leagues. ABC Australia. Retrieved from https://www. abc.net.au/news/2020-04-18/chance-for-aflw-other-womens-leagues-reboot-aftercovid-19/12152966

ESPN PR. (2020, April 21). WNBA Draft 2020: Most-watched WNBA Draft since 2004. Tweet. Retrieved from https://twitter.com/ESPNPR/status/1252604561870725120

Faller, M.B. (2019, March 30). Looking at sports as a microcosm of racial, gender disparities in society. Paper presented at the Global Sport Summit, Arizona State University, Tempe, AZ. Retrieved from https://law.asu.edu/looking-sportsmicrocosm-racial-gender-disparities-society

FIFA Staff. (2019, October 18). FIFA Women's World Cup 2019 watched by more than 1 billion. FIFA.com. Retrieved from https://www.fifa.com/womensworldcup/news/ fifa-women-s-world-cup-2019tm-watched-by-more-than-1-billion

Fine, M. (2020, April 29). COVID-19 and women's sport: Another casualty of gender inequality? Forbes.com. Retrieved from https://www.forbes.com/sites/melaniefine/ 2020/04/29/covid-19-and-womens-sports-another-casualty-of-gender-inequity/\#5b9db $5 \mathrm{~d} 261 \mathrm{~b} 0$

Gibbs, L. (2020, April 24). A tale of two drafts. Power Plays. Retrieved from https://www. powerplays.news/p/a-tale-of-two-drafts

Gibson, C. (2020, March). Trailblazing NBA women coaches. espnW.com. Retrieved from http://www.espn.com/espn/feature/story/_/id/28744241/trailblazing-nba-women-coaches

Giorgio, P. (2020). 2020 sports industry outlook. NY: Deloitte Technology, Media, and Telecommunications. Retrieved from https://www2.deloitte.com/us/en/pages/technologymedia-and-telecommunications/articles/sports-business-trends-disruption.html

Hillier, B. (2020, May 14). Women's pro soccer made gains toward parity. Will coronavirus undo it? PRI.org. Retrieved from https://www.pri.org/stories/2020-05-14/women-spro-soccer-made-gains-toward-parity-will-coronavirus-undo-it

Just Women's Sport. (2020, April 17). Retrieved from https://www.justwomenssports.com/ womens-sports-schedule 
Kaplan, E. (2020, March 8). What comes next in the professional women's hockey saga? ESPN.com. Retrieved from https://www.espn.com/nhl/story/_/id/28846979/whatcomes-next-professional-women-hockey-saga

Kim, A. (2020, May 1). ESPN to air marble racing, cherry pit spitting and more weird sports this weekend. CNN.com. Retrieved from https://www.cnn.com/2020/05/01/us/espnocho-spt-trnd/index.html

Kirpalani, B. (2020, January 21). ESPN to air entire 2020 NCAA Division I Women's tournament nationally. Highposthoops.com. Retrieved from https://highposthoops. com/2020/01/21/espn-to-air-2020-ncaa-division-i-womens-tournament-nationally/

Lapook, J. (2019, February 19). Former Team USA gymnasts describe doctor's alleged sexual abuse. CBSNews.com. Retrieved from https://www.cbsnews.com/news/formerteam-usa-gymnasts-describe-doctors-alleged-sexual-abuse-60-minutes-2019-08-09/

Lewis, H. (2020, March 19). The coronavirus is a disaster for feminism: Pandemics affect men and women differently. The Atlantic. Retrieved from https:/www.theatlantic.com/ international/archive/2020/03/feminism-womens-rights-coronavirus-covid19/608302/

Macur, J. (2020, March 21). Coronavirus compounds financial concerns in women's sport. The New York Times. Retrieved from https://www.nytimes.com/2020/03/21/sports/ coronavirus-womens-sports.html

Mather, V. (2020, March 11). How the coronavirus is disrupting sports events. The New York Times. Retrieved from https://www.nytimes.com/2020/03/11/sports/coronavirus-sports. html

Megdal, H. (2020, January 14). W.N.B.A. makes 'big best on women' with a new contract. The New York Times. Retrieved from https://www.nytimes.com/2020/01/14/sports/ basketball/wnba-contract-collective-bargaining-agreement.html

Minsberg, T. (2020, March 14). An important year for women's sport paused by coronavirus. The New York Times. Retrieved from https://www.nytimes.com/2020/03/14/ sports/womens-sports-coronavirus.html

Osburn, S. (2020, March 12). NCAA cancels remaining men's and women's championships. NCAA press release. Retrieved from https://www.ncaa.org/about/resources/ media-center/news/ncaa-cancels-remaining-winter-and-spring-championships

Peterson, A. (2020, April 16). Women's sport likely to bear brunt of coronavirus fallout. The New York Times. Retrieved from https://www.nytimes.com/aponline/2020/04/16/ sports/ap-virus-outbreak-womens-sports.html

Petrucelli, S. (2020, April 19). Don't let pandemic reverse gains in women's sports. Long Island Press. Retrieved from https://www.longislandpress.com/2020/04/19/dont-letpandemic-reverse-gains-in-womens-sports/

Pickman, B. (2020, March 26). How COVID-19 is affecting female athletes, women's sports leagues. Sports Illustrated. Retrieved from https://www.theguardian.com/sport/2020/ mar/19/rapid-rise-of-womens-sport-at-risk-of-being-halted-by-covid-19-outbreak

Pinsker, J. (2020, April 10). The pandemic will cleave America in two. The Atlantic. Retrieved from https://www.theatlantic.com/family/archive/2020/04/two-pandemicsus-coronavirus-inequality/609622/

Reuters. (2020, May 6). Merger with ATP 'makes all the sense in the world'-WTA chief Steve Simon. ESPN.com. Retrieved from https://www.espn.com/tennis/story/_id/ 29141352/merger-atp-makes-all-sense-world-wta-chief-steve-simon

Satam, S. (2020, April 22). "That was confidential"-Serena Williams responds to Roger Federer. Essentiallysports.com. Retrieved from https://www.essentiallysports.com/thatwas-confidential-serena-williams-responds-to-roger-federer-atp-wta-tennis-news-2020/

Shalala, A. (2020, April 15). Coronavirus pandemic threatens to halt momentum of women's sport teams in Australia. ABC.net.au. Retrieved from https://www.abc.net. $\mathrm{au} /$ news/2020-04-16/coronavirus-threatens-to-halt-momentum-of-womens-sport-australia/ 12149624 
Smith, R. (2020, April 10). Women's soccer was having a moment. Then the clock stopped. The New York Times. Retrieved from https:/www.nytimes.com/2020/04/10/sports/ soccer/womens-soccer-coronavirus-glasgow-city.html

Spain, S. (2020, April 23). The women who will literally be plugged in to the virtual NFL draft. ESPN.com. Retrieved from https://www.espn.com/espnw/story/_id/29084329/ the-women-literally-plugged-virtual-nfl-draft

Spencer, D. (2020, April 20). Pandemic strikes at a pivotal time in women's professional hockey. The Richmond News. Retrieved from https://www.richmond-news.com/ pandemic-strikes-at-a-pivotal-time-in-women-s-professional-hockey-1.24121155

Staurowsky, E.J., Watanabe, N., Cooper, J., Cooky, C., Lough, N., Paule-Koba, A., . . Snyder, M. (2020). Chasing Equity: The triumphs, challenges, and opportunities in sports for girls and women. New York, NY: Women's Sports Foundation. Retrieved from https://www.womenssportsfoundation.org/wp-content/uploads/2020/01/ChasingEquity-Full-Report-Web.pdf

Steinberg, B. (2019, April 22). CBS Sports, WNBA strike TV deal. Variety.com. Retrieved from https://variety.com/2019/tv/news/cbs-sports-wnba-tv-rights-deal-1203194367/

Thomas, I. (2020, March 9). Female sports executives see growth ahead, as well as challenges. Front Office Sports. Retrieved from https://frntofficesport.com/femaleexecutive-roundtable-2020/

Townes, C. (2020, April 28). How Thayer Lavielle, an executive with Wasserman, thinks COVID-19 can be an opportunity not a loss for women's sports. Forbes.com. Retrieved from https://www.forbes.com/sites/ceceliatownes/2020/04/28/an-executive-with-aplan-for-protecting-womens-sports-from-covid-19/\#44204ae517c3

USA Basketball Staff. (2019, June 15). Carol Callan elected FIBA Americas president. USAB.com. Retrieved from https://www.usab.com/news-events/news/2019/06/carolcallan-fiba-americas-president.aspx

Verdola, S. (2019, October 25). I was a pro but felt like a part-time worker. Crosscut.com. Retrieved from https://crosscut.com/2019/10/i-was-pro-felt-part-time-worker-futurewomens-soccer-doesnt-have-feel-same

Voepel, M. (2020, April 27). Diana Taurasi wants to enter ownership. ESPN.com. Retrieved from https://www.espn.com/wnba/story/_id/29102056/diana-taurasi-wants-enter-ownershipquestions-lack-women-investing-sports

Wertheim, J. (2020, April 29). Is Roger Federer's ATP-WTA merger proposal realistic? SI.com. Retrieved from https://www.si.com/tennis/2020/04/29/atp-wta-merger-menswomens-tennis-federer-mailbag

Wetzel, D. (2020, April 7). \#WeKeepPlaying: Women's Sports Foundation leads charge to nurture young girls amid pandemic. Yahoo!Sports.com. Retrieved from https://sports. yahoo.com/billie-jean-king-womens-sports-foundation-wekeepplaying-140137261.html 